Acta Universitatis Nicolai Copernici • Pedagogika XXXII/2016

Nauki Humanistyczno-Społeczne • Zeszyt 435

DOI: http://dx.doi.org/10.12775/AUNC_PED.2016.004

Łukasz Kempiński

Akademia Pomorska w Słupsku

\title{
EDUKACJA REGIONALNA - WYZWANIA NAUCZYCIELI I REGIONALISTÓW
}

\section{Wprowadzenie}

T ongres Kociewski, odbywający się cyklicznie od 1995 r. co pięć Llat, stwarza doskonałą możliwość do przeprowadzenia różnego rodzaju inicjatyw, ukazujących olbrzymi zakres działań promujących region - Kociewie ${ }^{1}$. To także czas, kiedy dochodzi do wymiany poglądów, oceny przedsięwziętych działań, a także spotkań przedstawicieli różnych instytucji kulturalnych, samorządów, szkół, muzeów, izb regionalnych, środowisk akademickich oraz lokalnych pasjonatów i miłośników regionu. V Kongres Kociewski, którego obchody odbyły się w 2015 r., również obfitował w różnego rodzaju wydarzenia, które przebiegały w głównych miastach regionu, a mianowicie w: Tczewie, Starogardzie Gdańskim i Świeciu. To właśnie tutaj na południowym Kociewiu w Świeciu, jednym z najstarszych miast Pomorza Nadwi-

1 To drugi co do wielkości (po Kaszubach) region Pomorza. Jego obszar obejmuje około $3100 \mathrm{~km}^{2}$ powierzchni, w większości należący do województwa pomorskiego (28\% leży w województwie kujawsko-pomorskim). Położenie regionu wyznacza wschodni brzeg stukilometrowego odcinka dolnej Wisły, od południa zaś granicę Kociewia wyznaczają miejscowości Łążek, Drzycim i Gruczno. Południowo-wschodnia część Kociewia administracyjnie należy do powiatu świeckiego. 
ślańskiego, położonym u ujścia rzeki Wdy do Wisły, zorganizowano dwa ważne wydarzenia: Plachandry Edukacyjne z uczbó... i seminarium naukowe Południowe Kociewie: tożsamość - edukacja - świadomość regionalna.

Jako że autor uczestniczył w pracach organizacyjnych i przygotowujących wyżej wymienione inicjatywy, czuje się w obowiązku przedstawić czytelnikowi główne idee, jakie przyświecały obu wydarzeniom. Plachandry Edukacyjne z uczbó... odbyły się 9 października 2015 r. w Gimnazjum nr 2 im. Mikołaja Kopernika w Świeciu. Nad organizacją całości czuwał Ośrodek Oświaty i Wychowania w Świeciu oraz nauczyciele - liderzy, koordynatorzy działań na każdym etapie edukacyjnym, począwszy od przedszkoli, szkoły podstawowe, gimnazja, aż po szkoły ponadgimnazjalne. Plachandry² dały możliwość przedstawienia, w bardzo różnorodny sposób, poprzez programy artystyczne, prezentacje multimedialne, wystąpienia regionalistów, wszelkich działań, jakie podejmują i realizują uczniowie oraz nauczyciele na rzecz promocji Kociewia i pielęgnowania lokalnego języka, tradycji i historii. Autor ograniczy się do zaprezentowania najważniejszych inicjatyw realizowanych przez nauczycieli świeckich gimnazjów, bowiem z III etapem edukacyjnym związany jest zawodowo ${ }^{3}$.

Uczeń gimnazjum to wymagający odbiorca prezentowanych mu treści z zakresu edukacji regionalnej. Nauczyciele starają się ukazać uczniom różnorodność tkwiącą w pojęciach: najbliższy region, kultura materialna i duchowa regionu, mieszkańcy regionu, bogactwo regionu jako część bogactwa narodowego, kultura języka wyrażająca się W postawie wobec jego odmian, tolerancja „inności”" ${ }^{\text {. W ramach }}$ projektów edukacyjnych realizowanych na zajęciach kół językoznawczych uczniowie zredagowali m.in. Słowniczek wyrazów kłopotliwych

2 Stary, kociewski wyraz oznaczający wyjście z domu, wędrówkę by kogoś spotkać, coś zobaczyć.

3 Autor artykułu jest nauczycielem historii i wiedzy o społeczeństwie w Gimnazjum nr 1 im. Ziemi Świeckiej w Świeciu.

${ }_{4}$ E. Zielińska, Edukacja regionalna $w$ Gimnazjum nr 2 im. Mikołaja Kopernika w Świeciu, w: Kociewskie Stecki (Zeszyty kociewskie), pod red. M. Pajakowskiej-Kensik, Świecie 2015, s. 34. 
gimnazjalisty. Takie działania miały skłaniać młodzież do rozpoznawania cech kultury i języka swojego regionu.

Obowiązkiem szkoły jest wyposażenie ucznia w pewien zasób wiedzy o tradycji kulturowej swojego regionu. Najlepiej przez rozbudzanie jego aktywności artystycznej i twórczej wyrażającej się przez udział w programach artystycznych. Uczniowie gimnazjów ze Świecia mogli realizować się w zakresie edukacji regionalnej, przygotowując następujące projekty edukacyjne: Kociewie - tradycje i obyczaje wielkanocne, O Bożym Narodzeniu, czyli jak na Kociewiu bywało i jeszcze bywa. Uczniowie Gimnazjum nr 3 w Świeciu zaprezentowali przedstawienie pt. „Kociewska uczba”, na podstawie książki Barbary Pawłowskiej U nas, na Kociewiu ${ }^{5}$. W inscenizacji młodzi aktorzy pokazali, jak kiedyś wyglądała „uczba” na Kociewiu i jak przygotowywano się na pierwszy dzień w szkole, zaprezentowano szkolne przyrządy, a także dawne gry i zabawy. Kolejną możliwością zaspokajania dążeń twórczych uczniów jest organizowany co roku konkurs recytatorski Poeci z Kociewia.

Edukacja regionalna to także edukacja historyczna, która koncentruje się głównie na promocji historii miasta i obszarów przyległych. Uczniowie, angażując się w różne projekty edukacyjne i uczestnicząc w zajęciach pozalekcyjnych, zgłębiali swoją wiedzę, a także promowali ważne dla miasta wydarzenia historyczne. Różnorodne działania gimnazjalistów prezentowano mieszkańcom miasta. Przykładem były następujące projekty edukacyjne: Miejsca walki i męczeńskiej śmierci na terenie powiatu świeckiego w czasie II wojny światowej i Żołnierze Wyklęci - działalność podziemia antykomunistycznego $w$ powiecie świeckim $w$ latach 1945-1963. Omawianie problematyki historycznej terenu, z którym bezpośrednio związana jest szkoła i uczęszczający do niej uczeń, ułatwia nauczycielowi zilustrowanie prawidłowości procesu historycznego. Dlatego bardzo sprawdzonym sposobem na zgłębianie historii małej ojczyzny jest organizowanie żywych lekcji historii, spacerów historycznych czy lekcji muzealnych. Nieoceniona w realizacji tych celów wydaje się rola Izby Regionalnej im. Ziemi Świeckiej6.

5 B. Pawłowska, U nas, na Kociewiu: scenki gwara, Skórcz 2011.

6 Szerzej w: Ł. Kempiński, Izba Regionalna jako depozytariusz pamięci mieszkańców Świecia i jego regionu, referat wygłoszony 25.11.2014 r. w Słupsku pod- 
Popularyzacja wiedzy historycznej możliwa jest również dzięki organizacji konkursów. Przykładem może być organizowany corocznie Bieg po zabytkach Świecia czy Międzyszkolny konkurs wiedzy o regionie. Ponadto realizowana $\mathrm{z}$ rozmachem turystyka przybliża uczniom walory przyrodnicze i architektoniczne bliskiego im otoczenia.

Tak szeroki zakres działań możliwy jest dzięki dobrej współpracy nauczycieli, regionalistów i lokalnych pasjonatów. Ważne i widoczne jest wsparcie czy współpraca z władzami samorządowymi. To dobrzy i niezawodni partnerzy. Dzięki ich zaangażowaniu zorganizowano 21 listopada 2015 r. wspomniane wcześniej seminarium naukowe Południowe Kociewie: tożsamość - edukacja - świadomość regionalna. Spotkali się tam przedstawiciele kilku ośrodków akademickich, aby wymienić poglądy, przedstawić i podsumować dotychczasowe przedsięwzięcia podejmowane w powiecie świeckim w ramach V Kongresu Kociewskiego, a także zachęcić do dyskusji na temat tożsamości regionalnej i dziedzictwa kulturowego Kociewia.

\section{Stan badań}

Pisząc o edukacji regionalnej nie da się pominąć kluczowego pojęcia, jakim jest termin „region”. Stanowi on punkt wyjścia dla rozważań Autorów ${ }^{7}$ na temat tego, co wewnątrz regionu może się dziać, zmieniać oraz jakie procesy historyczne i społeczne wpływają na region. W przywołanych publikacjach czytelnik będzie mógł odnaleźć odpowiedzi na wiele pytań dotyczących badania i interpretowania rzeczy-

czas XIII Konferencji Kaszubsko-Pomorskiej - „Kulturowe konteksty pamięci Pomorzan".

7 A. Awramiuk, Pogranicze kultur percepcja „własnego regionu” przez uczniów a edukacja regionalna, Warszawa 2009; J. Damrosz, Ojczyzna i jej regiony: (region, regionalizm, edukacja lokalno-regionalna i etniczna), Warszawa-Płock 2007; tegoż: Region i regionalizm: (studium interdyscyplinarne), Warszawa 1987; Polskie regiony: podstawy kulturowe regionalizacji Polski. pod red. E. Wysockiej i M. Konopki, Ciechanów 1997; Region, tożsamość, edukacja, red. nauk. J. Nikitorowicz, D. Misiejuk, M. Sobecki, Białystok 2005; Symbolika regionów: studia etnologiczno-folklorystyczne, pod red. D. Simonides, Opole 1988. 
wistości regionu, których udzielili badacze reprezentujący dyscypliny humanistyczne i społeczne. Proces przekazywania wiedzy o tym, co nas bezpośrednio otacza, może zachęcać do dyskusji.

W tematykę ogólnie pojmowanej edukacji regionalnej wprowadza czytelnika wiele publikacji ${ }^{8}$. Dzięki właściwemu doborowi tematów może on prześledzić historię zainteresowań tą problematyką (dzieje edukacji regionalnej), sposoby jej badania i interpretowania. Autorzy wskazują ważne płaszczyzny, z perspektywy których można badać region. Ciekawe ujęcie interesujących nas zagadnień przedstawia Piotr Petrykowski ${ }^{10}$ i Jerzy Nikitorowicz ${ }^{11}$. Cenna jest również praca zbiorowa pod redakcją Stefana Bednarka ${ }^{12}$.

Dla osób zainteresowanych regionalizmem na Kociewiu ważną lekturą jest opracowanie pod redakcją Ireny Bruckiej ${ }^{13}$, Jerzego Cherka14,

8 A. Patkowski, Idee przewodnie regionalizmu, „Małopolska”, t. 6 (2004), s. 153-162; Region i ludzie a historiografia i tożsamość: materiały z II Zjazdu Historyków Regionalistów w Gdańsku-Starbieninie, 22-24 XI 1996, zeb. i wst. opat. J. Borzyszkowski, Ciechanów 1999; Regionalizm a historia: materiały IV Krajowego Forum Regionalistycznego, Staszów-Sandomierz 25-27 września 1997 r., pod red. M. A. Zarębskiego, Staszów 1998; W hołdzie Aleksandrowi Patkowskiemu: (w setna rocznicę urodzin), pod red. J. Grzywny, A. Rembalskiego, Kielce 1991; A. Błachowski, Etnografia: ścieżka edukacji regionalnej: podręcznik dla nauczycieli, t. 1, Toruń 2003; Edukacja regionalna, pod red. A. W. Brzezińskiej, A. Hulewskiej, J. Słomskiej, Warszawa 2006; Edukacja regionalna: z historii, teorii i praktyki, pod red. M.T. Michalewskiej, Kraków 1999; Nauczanie historii na miarę XXI wieku: region, patriotyzm, edukacja, pod red. Z. Biegańskiego, T. Maresz, Bydgoszcz 2010.

9 Edukacja regionalna. Dziedzictwo kulturowe $w$ zreformowanej szkole, pod red. S. Bednarka, Wrocław 1999.

10 P. Petrykowski, Edukacja regionalna: problemy podstawowe i otwarte, Toruń 2003.

11 J. Nikitorowicz, Edukacja regionalna i międzykulturowa, Warszawa 2009.

12 Edukacja regionalna. Dziedzictwo kulturowe $w$ zreformowanej szkole, pod red. S. Bednarka, Wrocław 1999.

13 Uczba na Kociewiu. Wskazówki do edukacji regionalnej - podręcznik dla nauczycieli, pod red. I. Bruckiej, Tczew 1997.

${ }^{14}$ Księga Pamiątkowa II Kongresu Kociewskiego, pod red. J. Cherek, Starogard Gdański 2002. 
Romana Landowskiego ${ }^{15}$ oraz zbiór materiałów pokonferencyjnych wydanych pod wspólnym tytułem Tu jest ojczyzna moja ${ }^{16}$. Autor niniejszego artykułu zdaje sobie sprawę, że przywołane publikacje nie wyczerpują problematyki tak złożonej i wciąż rozwijającej się dyscypliny, jaką jest edukacja regionalna. A próba opracowania obszernego kompendium wiedzy traktującego o prowadzonych badaniach, o regionie i edukacji regionalnej jest na tym etapie przedwczesna. Artykuł ten jest więc pewnego rodzaju podsumowaniem i próbą prezentacji wyzwań, trudności z jakimi spotykają się nauczyciele i regionaliści śmiem twierdzić - z całej Polski.

\section{Region, Regionalizm}

To określenia używane w wielu znaczeniach. Zakres semantyczny jest różny w zależności od uprawianej dyscypliny naukowej. Najogólniej określona definicja „regionu” stwierdza, że jest to przestrzeń, posiadająca cechy wyróżniające ją od innych obszarów. Według Wspólnotowej Karty Regionalizacji ${ }^{17}$ „przez region rozumie się terytorium, które z geograficznego punktu widzenia stanowi wyraźną całość bądź też stanowi jednolity kompleks terenów, które tworzą zamkniętą całość, a których ludność charakteryzują określone wspólne elementy, przy czym chciałaby ona utrwalić i rozwinąć pewne wynikające z nich właściwości, aby pobudzić postęp kulturalny, społeczny i gospodarczy"18. Tymczasem pojęcie regionu należy do wieloznacznych. Jeżeli ma być zastosowane $\mathrm{w}$ dyskursie naukowym, to musi być dosyć precyzyjnie zdefiniowane na gruncie danej nauki, która chce się nim posługiwać.

15 R. Landowski, Nowy Bedeker Kociewski, Gdańsk 2002; tegoż: Dawnych obyczajów rok cały. Między wiara, tradycją i obrzędem, Pelplin 2000; tegoż: Kultura ludowa Kociewia, Tczew 2005.

16 Tu jest Ojczyzna moja. Materiały z konferencji „Edukacja regionalna - dziedzictwo kulturowe w regionie", Gdańsk 1999.

17 Szerzej w: K. Jóskowiak, Unia Europejska a profil jego międzynarodowej współpracy na poziomie lokalnym i regionalnym $w$ przyszłości, „Studia Europejskie" 3/2008, s. 106-107.

18 Cyt. za: J. Nikitorowicz, Idee edukacji $w$ warunkach wielokulturowości, w: Edukacja Regionalna..., s. 217. 
Trudne okazuje się wypracowanie jednej ogólnej definicji regionu ${ }^{19}$, którą mogłyby stosować wszystkie nauki. Tymczasem pojęcie regionu jest używane w wielu dziedzinach i dyscyplinach naukowych: w naukach o ziemi, ekonomicznych, prawnych, humanistycznych i społecznych ${ }^{20}$.

Nawet w określonej dziedzinie nauki pojęcie regionu jest definiowane na wiele sposobów. I tak np. w humanistyce inaczej je będzie określał językoznawca, folklorysta, kulturoznawca, etnograf, pedagog czy socjolog. Zależy to, z jednej strony, od specyfiki przedmiotu badań danej nauki, a z drugiej strony od tego, pod jakim kątem ten przedmiot jest poznawany. Nie bez znaczenia jest również zakres kompetencji merytorycznych badacza. Trafnie określił tę szczególną właściwość pojęcia region Karol Buczek, stwierdzając że „niewiele chyba mamy naukowych terminów używanych równie beztrosko i dowolnie jak słowo region. Terminem tym można oznaczać w zasadzie każdy większy lub mniejszy obszar, który różni się od innych jakąś określoną właściwością lub określonymi właściwościami, albo przynajmniej swoim położeniem"21. Stąd regionami określa się obszary, na których wyodrębniły się określone cechy, a ich mieszkańcy mają silne poczucie własnej tożsamości i świadomość zwyczajów, i systemu wartości.

$\mathrm{Z}$ definicją regionu nierozerwalnie łączy się pojęcie regionalizmu. Termin „regionalizm” pojawił się pierwszy raz w 1874 r. we Francji. Definiuje go Leon de Berluc-Perussis, ale terminologia ta upowszechniła się dopiero około $1892 \mathrm{r}^{22}$. Początkowo pojęcie to odnosi się do postaw związanych z ruchami społeczno-kulturowymi, dążącymi do zachowania swoistych elementów kultury regionu (kultury etnicznej, grupowej) i innych charakterystycznych przymiotów danego terenu.

19 J. Turowski, Regiony - regionalizm - lokalizm (wymienia pięć możliwych sposobów rozumienia pojęcia region), w: Czym jest regionalizm, red. S. Bednarka, Wrocław-Ciechanów 1998, s. 100-116.

20 J. Styk, Pojęcie regionu $w$ badaniach naukowych, http://www.umcs.pl/pl/ pojecie-regionu-w-badaniach-naukowych [dostęp: 25.01.2016].

21 K. Buczek, O regionach historycznych, „Małopolskie Studia Historyczne”, z. 3/4, 1966, s. 144 .

22 R. Bieniada, Regionalizm i regionalizacja $w$ definicji. Wybrane problemy teoretyczne, „e-Politikon”, 6/2013, s. 282. 
Pełny rozwój regionalizmu następuje u schyłku XIX w. Wówczas pojęcie funkcjonuje jako określenie pewnej separacji ruchu społecznego i kulturalnego na danym terytorium. W ramach tego ruchu wzmacnia się poczucie odrębności, zachęca do realizacji zadań zmierzających do zachowania swoistych cech kultury.

Dzisiaj regionalizm traktuje się jako aktywność społeczności danego terytorium, której celem jest odrodzenie, utrzymanie odrębności kulturowej określonego regionu, opanowanie i propagowanie wiedzy o nim oraz kultywowanie typowych właściwości regionu. Regionalizm jest więc postawą szczególną wobec własnej przestrzeni terytorialnej, czyli małej ojczyzny. Zdaniem regionalistów współcześnie regionalizm w Polsce przejawia zainteresowanie także tradycjami kulturowymi i historycznymi. Cały regionalny ruch kulturowy jest oparty na szeroko pojętej aktywności i inicjatywach społecznych, stwarza możliwość samorealizacji i spontaniczności w działaniu ${ }^{23}$. Regionalizm pozwala na kreatywność w stosowaniu różnorodnych treści i form w działaniu, dzięki czemu zachęca społeczność danego obszaru do aktywności artystycznej. Z całą pewnością stwierdzić można, że rozwijane idee regionalizmu w Polsce pomagają współczesnemu człowiekowi odnaleźć się w otaczającej go rzeczywistości. Człowiek ma znowu czuć się u siebie, być zadomowionym i zakorzenionym.

\section{Edukacja regionalna w Polsce - rys historyczny}

W historii polskiego regionalizmu olbrzymie znaczenie ma okres międzywojenny. To właśnie wtedy, w 1926 r., powstał „Program Regionalizmu Polskiego”24. Dokument podkreślał dążenie regionalizmu do

23 P. Petrykowski, Edukacja regionalna: problemy..., s. 105.

24 „W roku 1926 Zarząd Sekcji Powszechnych Uniwersytetów Regionalnych Związku Polskiego Nauczycielstwa Szkół Powszechnych ogłosił drukiem program regionalizmu polskiego jako podstawę swej działalności. Program ukazał się drukiem w numerze 4-5 „Polskiej Oświaty Pozaszkolnej” z 1926 r., na stronach 221-223" (Archiwum Związku Nauczycielstwa Polskiego w Warszawie, Związek Polskiego Nauczycielstwa Szkół Powszechnych Zarząd Główny, Program regionalizmu polskiego. Materiały dotyczące opracowania i publikacji 1925-1929, sygn. 303). 
„jak najszerszego związania pracy wychowawczo-oświatowej w szkole i poza szkołą ze środowiskiem lokalnym"25. Jeden z twórców Programu - Aleksander Kazimierz Patkowski, czołowy teoretyk i ideolog regionalizmu, proponował edukację regionalną służącą aktywizacji społecznej, kulturalnej i gospodarczej poszczególnych regionów, co w konsekwencji potęgowało wzmocnienie społecznych, kulturalnych i ekonomicznych podstaw poszczególnych obszarów II Rzeczypospolitej. Ten regionalny rozwój rozszerzyć miał proces integracji szkolnictwa wszystkich szczebli. Szkoła winna być zlokalizowana i funkcjonować w konkretnym środowisku oraz ściśle współpracować z jego pozostałymi instytucjami ${ }^{26}$. Zdaniem Patkowskiego nauczanie poszczególnych przedmiotów w szkole miało przybliżać je do życia i konkretnego środowiska. Postulował zmiany w nauczaniu języka polskiego, historii, geografii i nauk przyrodniczych, gdzie nowe podręczniki i treści edukacyjne miały być dostosowane do wymogów terenu, na którym funkcjonowała szkoła oraz charakteryzować region i jego specyficzne warunki. Cały proces oświatowo-wychowawczy tkwiący w lokalnych środowiskach miał uwzględniać ich bieżące potrzeby, kształtować poczucie przynależności do określonego terenu, zachęcać do podejmowania działań na rzecz tej „małej” ojczyzny, będącej częścią tej ojczyzny „wielkiej”.

Realizowanie założeń regionalizmu było powinnością stanu nauczycielskiego. Po 1956 r. większość pedagogów przeniosła swoją działalność do stowarzyszeń regionalnych i krajoznawczych, a przy sprzyjających okolicznościach, np. obchodach Millenium Chrztu Polski, podejmowała różne działania w zakresie edukacji historycznej, tworzenia izb i muzeów regionalnych. Ponadto nauczyciele byli autorami publikacji traktujących o historii i dziedzictwie kulturowym swoich miejscowości oraz prowadzili naukowe koła historyczne czy krajo-

25 A.J. Omelaniuk, Regionalizm wspótczesny - jego znaczenie $i$ rola $w$ procesie oddziaływania na młodzież u progu XXI w., w: Edukacja regionalna. Dziedzictwo..., pod red. S. Bednarka, Wrocław 1999, s. 56.

26 D. Żołądź-Strzelczyk, W. Jamrożek, Edukacja regionalna w ujęciu Aleksandra Kazimierza Patkowskiego, w: Edukacja Regionalna, pod red. A.W. Brzezińskiej, A. Hulewskiej, J. Stomskiej, Warszawa 2006, s. 120. 
znawcze. W latach 80-tych ubiegłego wieku postulowano odrodzenie regionalizmu jako ideologii. W 1989 r. przedstawiono ówczesnym władzom stanowisko Narodowej Rady Kultury dotyczące edukacji regionalnej, ale niestety pozostało ono bez echa. Dopiero 25 września 1994 r. na V Kongresie Regionalnych Towarzystw Kultury we Wrocławiu uchwalono Kartę Regionalizmu Polskiego. Punkt 6 dokumentu stwierdzał następująco: „Szczególna rola w podtrzymywaniu i kształtowaniu świadomości lokalnej i regionalnej przypada systemowi edukacji. Programy nauczania szkół wszystkich szczebli powinny szeroko uwzględniać tematykę regionalną"27.

Dzisiaj wśród zadań wychowawczych formułowanych w nowej podstawie programowej wskazuje się, że w procesie kształcenia ogólnego szkoła ma stać się miejscem przekazu dziedzictwa kulturowego, przede wszystkim wspierać ucznia w rozumieniu zachodzących współcześnie zmian społeczno-kulturowych, w dobie integracji i globalizacji. Ma także podjąć odpowiednie kroki, by przygotować i wprowadzić młodego człowieka do roli aktywnego, odpowiedzialnego współgospodarza regionu i kraju oraz uczestnika życia wspólnoty europejskiej (poprzez umożliwienie zdobywania wszechstronnej wiedzy o własnym regionie). W tym zapisie można więc upatrywać zasadniczy cel i istotę edukacji regionalnej, które formułuje Piotr Petrykowski w stwierdzeniu, że jest ona „ukształtowaniem w młodych jednostkach poczucia własnej tożsamości regionalnej jako postawy zaangażowania się w funkcjonowanie własnego środowiska oraz autentycznego otwarcia się na inne społeczności i kultury"28.

\section{Założenia, zadania i funkcje edukacji regionalnej}

Kim jest uczeń-odbiorca, uczestnik procesu edukacyjnego? Jaka rola przypada nauczycielowi, regionaliście, nauczycielowi-wychowawcy? Przed jakimi staje on wyzwaniami? Wreszcie - jaką rolę winna pełnić edukacja regionalna $\mathrm{w}$ polskim systemie oświaty?

27 http://www.wtk.poznan.pl/www2/pw/27-28/KartaRegionalizmu.html [dostęp: 14.11.2015].

28 P. Petrykowski, Edukacja regionalna..., s. 52. 
Uczeń, na szczęście nie każdy, otoczony kulturą masową, uczestnik globalnego życia w sieci, często nie ma zwyczajnie chęci na to, aby mocniej zaangażować się w działalność na rzecz środowiska lokalnego. Czasami postrzega edukację regionalną jako mało interesującą bądź zwyczajnie nie ma na nią czasu. Ale gdy ukaże się uczniowi, że regionalizm ma pomóc mu rozwijać jego patriotyzm lokalny, a przez to rozwijać poczucie bycia „u siebie”, bycia zadomowionym i zakorzenionym, to okaże się, że jednostka wśród ofert makroświata pozytywnie odniesie się do podstawowych wartości rdzennych takich, jak: język matczyny, zasiedziałość terytorialna, genealogia historyczna, tradycje, obyczaje, zasady i normy zachowań w ojczyźnie prywatnej ${ }^{29}$. Ponadto uczeń będzie chętniej angażować się w życie lokalnego środowiska na różnych płaszczyznach, gdy tylko da mu się taką możliwość i odpowiednio zachęci. Duże pole działania w tym zakresie mają nauczyciele prowadzący różnego typu przedmiotowe koła zainteresowań, jak na przykład: historyczne, językoznawcze, geograficzne czy turystyczno-krajoznawcze. Należy wytworzyć w uczniach przeświadczenie, że wiedza, którą zdobywają nie jest stratą czasu, ale ma ona pomagać w odkrywaniu obszarów dotąd nieznanych bądź całkowicie zapomnianych.

Aby wzbudzić taką aktywność w uczniach, niezmiernie ważna jest rola nauczyciela, regionalisty. Przy haśle „nauczyciel” trzeba powiedzieć, że warto zwrócić uwagę na to, by nauczyciele podejmujący problematykę edukacji regionalnej, byli nauczycielami, jak to się zwykło mawiać, $\mathrm{z}$ powołania, zakochanymi $\mathrm{w}$ swoim regionie, broniącymi swojego zakorzenienia właśnie w tej rzeczywistości, w której żyją ${ }^{30}$. Nie ulega wątpliwości, że główną rolę w procesie nauczania każdego przedmiotu w szkole spełnia nauczyciel. Od zasobu jego wiedzy, osobistego stosunku do nauczanego przedmiotu i umiejętności „zarażania" uczniów regionalizmem w dużej mierze zależy skuteczność kształcenia w duchu regionalizmu. W życiu szkoły ważna jest prosta

29 J. Nikitorowicz, Edukacja regionalna na pograniczach, w: Edukacja Regionalna..., s. 102.

30 W. Książek, Edukacja regionalna w polskiej reformie oświaty, w: Tu jest Ojczyzna moja. Materiały z konferencji „Edukacja regionalna-dziedzictwo kulturowe w regionie”, Gdańsk 1999, s. 15. 
idea „okna”31. Dobry nauczyciel to także autorytet w środowisku lokalnym, który w tej przestrzeni za „oknem” może zrealizować wiele zadań edukacyjnych. Nauczyciel winien wypracować takie działania edukacyjne, aby przygotować wszystkich odbiorców, niezależnie od pochodzenia i własnej kultury środowiskowej, do życia i współdziałania w swoim regionie. Możliwe to będzie dzięki przestrzeganiu i postępowaniu wg następujących reguł edukacyjnych ${ }^{32}$ :

- znajomości potrzeb ucznia, jego indywidualnych parametrów rozwoju, indywidualnych zainteresowań i zamiłowań, a przede wszystkim jego kulturowego usytuowania rodzinnego i lokalnego,

- operowaniu w praktyce wiedzą o aktywności ucznia jako podmiotu działającego;

- zapewnieniu możliwości umożliwienia swobodnego wyboru zadań, szukania możliwych sposobów realizacji i oceny pracy na rzecz lokalnej społeczności.

W przypadku nauczania regionalizmu nieefektywna wydaje się edukacja transmisyjna, w której aktywność ucznia ma głównie charakter recepcyjny, a treści są wskazywane jako niezbędne do realizacji w określonym czasie. Dlatego nauczyciel regionalista winien być mocno osadzony w środowisku lokalnym, występować w roli znawcy i kreatora regionu oraz powinien być twórczy, inicjujący, realizujący wspólnie z uczniami potrzeby społeczności. Misją nauczycieli-regionalistów jest konsekwentne dążenie do pobudzenia aktywności lokalnej. Działanie społeczne jednostek i grup tworzących społeczność lokalną, może wzmacniać poczucie identyfikacji z najbliższym otoczeniem, ułatwiając ożywienie lokalnego życia społecznego i inicjatyw kulturalnych ${ }^{33}$. Zaangażowani regionaliści są kołem zamachowym edukacji regionalnej.

Edukacja regionalna jest pewnym sposobem na rozumienie otaczającego nas świata. W ten sposób utrwala i upowszechnia się elementy kultury lokalnej. Edukowanie poprzez poznawanie najbliższego oto-

31 W. Książek, Znaczenie edukacji regionalnej, w: Księga Pamiątkowa II Kongresu Kociewskiego, pod red. J. Cherka, Starogard Gdański 2002, s. 166.

32 J. Nikitorowicz, Edukacja regionalna..., s. 221.

33 A.J. Omelaniuk, Regionalizm..., s. 63. 
czenia, powrót do źródeł kultury rodzinnej, lokalnej i regionalnej stanowi jeden ze środków do poznawania źródeł kultury ogólnoludzkiej i narodowej ${ }^{34}$. Jest to obszar, gdzie spotykają się specjaliści z różnych dziedzin, a elementami edukacji są: dziedzictwo archeologiczne i historyczne, turystyka i ekologia, elementy tradycyjnej kultury i sztuki ludowej, folklor muzyczny i taneczny oraz gwary. Na jednej płaszczyźnie dochodzi do spotkania różnorodnych elementów, charakteryzujących daną społeczność osadzoną w konkretnym miejscu. Przekazywanie wiedzy połączone z umiejętnością wnikliwej obserwacji najbliższej rzeczywistości winno skłaniać uczniów do prób podejmowania dyskusji o tym, co wokół nich się dzieje.

Realizowanie zadań z zakresu edukacji regionalnej jest wyzwaniem nie tylko dla szkół, nauczycieli, regionalistów, ale także dla lokalnych instytucji i organizacji. Na przykład działalność w stowarzyszeniach regionalnych z jednej strony daje dużo satysfakcji i - nie ukrywajmy lepszą rozpoznawalność w środowisku. Z drugiej jest absorbująca, wymaga czasu i zaangażowania. Ale, co najważniejsze, daje wymierne rezultaty tylko wtedy, gdy oparta jest na współdziałaniu, na budowaniu więzi międzyludzkich, na tworzeniu grupy naprawdę poczuwającej się do służby „małej ojczyźnie”. Jest to swoiste sprawdzenie możliwości i twórczego potencjału dla członków zbiorowości lokalnej35. Proces edukacyjny ma przebiegać w taki sposób, aby uczeń nie był tylko biernym odbiorcą, ale w pewnym sensie twórcą mającym wpływ na kształt swojego otoczenia.

Działalność edukacyjna powinna być ukierunkowana na doświadczanie i rozumienie rzeczywistości oraz dokonywanie zmian społecznych. Istotne jest stwarzanie odpowiednich warunków oraz wdrażanie do przemyślanych i świadomych działań z wykorzystaniem siły i mocy autorytetów. Ciągle żywy jest postulat Jerzego Maternickiego,

34 K. Kossak-Główczewski, Edukacja regionalna - pytania o realizację, w: Edukacja wobec zmiany społecznej, pod red. J. Brzezińskiego, L. Witkowskiego, Poznań-Toruń 1994, s. 244-264.

35 A.W. Brzezińska, Edukacja regionalna jako wyzwanie pedagogiczne dla etnologa, s. 147, https://repozytorium.amu.edu.pl/jspui/bitstream/10593/4918/1 [dostęp: 16.11.2015]. 
który stwierdził: „Trzeba wydobyć z zapomnienia lokalnych (regionalnych) działaczy społecznych, gospodarczych, oświatowych i politycznych, pokazać młodzieży, co zrobili dla swego środowiska, jak tego dokonali. To najlepsze wzory wychowawcze dla uczniów"36.

Aby podejmowane przez nauczycieli, regionalistów przedsięwzięcia dały efekty, to realizowana przez nich edukacja regionalna powinna być podporządkowana kilku zasadom ${ }^{37}$ :

- edukacja ma ułatwić znalezienie wspomnianego wcześniej „zakorzenienia" i kształtować poczucie grupowej społeczno-kulturowej tożsamości. Człowiek pozbawiony możliwości utożsamiania się z konkretną tradycją, ze wspólnotą większą od rodziny, lecz mniejszą od narodu, z obyczajem, historią, językiem czy dialektem niejako zatraca się $\mathrm{w}$ masie.

- edukacja regionalna ma przygotować do życia w ojczyźnie narodowej, w Europie i świecie, pozwolić lepiej zrozumieć to co ogólnonarodowe, uczyć patriotyzmu narodowego i lokalnego. Dlatego m.in. nie może być traktowana jako alternatywa dla edukacji narodowej czy ogólnej. Jest ich podstawową częścią, a nie ozdobnikiem czy modnym dodatkiem do tradycyjnego procesu dydaktyczno-wychowawczego.

- od edukacji regionalnej zależy przygotowanie do lepszego rozumienia innych jednostek i społeczności oraz tolerancja. Poznając własną odmienność i specyfikę kulturową, lepiej poznajemy ograniczenia własnego świata, stajemy się bardziej wyrozumiali na odmienność innych, umiemy „pięknie różnić się od innych” i poszukujemy sposobów wzajemnego zrozumienia, porozumienia i współpracy.

- kolejną funkcją edukacji regionalnej jest jej funkcja integracyjna. Trzeba pamiętać, że regionalizacja i decentralizacja w skali

36 J. Maternicki, Edukacja historyczna młodzieży. Problemy i kontrowersje u progu XXI wieku, Toruń 1998, s. 42.

37 B. Synak, Kilka uwag na temat społeczno-kulturowych funkcji i zasad edukacji regionalnej, w: Tu jest ojczyzna moja. Materiały z konferencji „Edukacja regionalna-dziedzictwo kulturowe w regionie”, Gdańsk 1999, s. 21-24. 
kraju oznaczać powinna równocześnie integrację w skali regionów.

- poprzez edukację regionalną buduje się społeczeństwo obywatelskie, wpaja oraz uczy zasady samorządności lokalnej i regionalnej. Uczy współpracy z władzami samorządowymi. Wiele inicjatyw regionalistów podejmowane jest dzięki ich wsparciu.

- poprzez waloryzację środowiska lokalnego i regionalnego, ich przyrody, kultury i historii edukacja regionalna winna przyczyniać się do wzmacniania poczucia nobilitacji i awansu społeczno-kulturalnego małych społeczności, leczyć z kompleksu wiejskości i prowincjonalizmu.

- szczególną uwagę zwracać należy na zróżnicowanie etniczności poszczególnych środowisk. Edukacja regionalna powinna kształtować poczucie wspólnoty i bogactwa kulturowego własnego regionu, a zwłaszcza musi być powiązana z innymi odniesieniami tożsamościowymi, z dziedzictwem narodowym jako tożsamością nadrzędną.

- jest wreszcie edukacja regionalna narzędziem budowania społeczeństwa obywatelskiego. Poczucie „bycia sobą i u siebie - tu i teraz", daje człowiekowi możliwość rozumienia swoich obowiązków i zadań, a w dalszej konsekwencji możliwość włączenia się w nurt życia własnego środowiska.

\section{Podsumowanie}

Z pełną odpowiedzialnością stwierdzić należy, że tu w Świeciu - stolicy Południowego Kociewia, powyższe założenia realizowane są z powodzeniem. Kociewski ruch regionalny wytycza sobie nowe zadania. Oprócz pielęgnowania i rozwijania tradycji kultury kociewskiej, dbania o zachowanie gwary, rozwój piśmiennictwa i aktywności wydawniczej, cały czas celem regionalistów winno być pobudzanie wszelkiej aktywności publicznej. Lokalne samorządy mają wspierać działania regionalistów. Nauczyciele zaangażowani w proces dydaktyczno-wychowawczy, jako aktywni członkowie regionalnego ruchu, w naturalny sposób mają pielęgnować i kształtować wśród młodzieży aktywną, 
otwartą postawę w funkcjonowaniu ich własnego środowiska. Zdobyta wiedza powinna uświadomić uczniowi autentyczne, otaczające go wartości. Są to wartości zarówno materialne, jak i duchowe, intelektualne, moralne, religijne. Chodzi o wydobycie całej sfery wartości, których nośnikiem jest kultura regionalna ${ }^{38}$. Ciągle należy poszukiwać i dbać o własny region i tożsamość kulturową. Jest to niezwykle ważne dzisiaj, w dobie społeczeństwa kultury masowej, nasilonej migracji ludności oraz gwałtownego oddziaływania mediów.

\section{Summary}

\section{REGIONAL EDUCATION: CHALLENGES AND THE DILEMMAS \\ OF TEACHERS AND REGIONALISTS}

The author of the article recapitulates the role of regional education in modern school and discusses some difficulties in implementing the scheme. He emphasizes the role of the teacher regionalist in activating students, who ought to be well - established in the local environment and act as both an expert and creator of the region. The educational process is to be conducted in such a way as to ensure that the student is not merely a passive recipient but, in a sense, a creator of the surrounding environment. Implementation of the tasks in the field of regional education poses a challenge not only for schools but also for local institutions and organizations. Thanks to cooperation, a wide range of activities is possible.

Keywords: regional education, teacher regionalist, the local environment, modern school

38 Uczba na Kociewiu. Wskazówki do edukacji regionalnej-podręcznik dla nauczycieli, pod red. I. Bruckiej, Tczew 1997, s. 9. 